culture and knowledge. Undoubtedly, the notion of power is not of key importance for constructivists. It is more a consequence of identity and socialization of entities in the international system.

In the evaluation of Anna Wojciuk's book, it needs to emphasised again that it is a pioneer attempt to show views on strength and power in theories of international relations. The objectives set by the author were largely fulfilled. Above all, the meticulous analysis of the latest world literature on the theory of international relations and presentation of views of researchers who are less known and popular in Poland deserve particular attention. It is a pity that so much attention in numerous Polish publications was devoted to American concepts, which are not always free from political influences. The author's research techniques and the excellent language are certainly worth noting. The issues brought up in the book are described in a way that is clear and understandable not only for people dealing with international relations. This publication can also be used as a teaching aid in classes devoted to the theory of international relations.

Katarzyna KĄCKA

Toruń

\title{
The Arab Spring, ed. Beata Przybylska-Maszner, Wydawnictwo Na- ukowe WNPiD UAM, Poznań 2011, ss. 295.
}

Year 2011 brought unexpected and profound changes in the political outlook of North Africa and Middle East. A wave of social protests, riots and (in some instances) violent confrontations created a situation of existential threat for the region's authoritarian regimes. The Arab world had been considered largely immune to rapid political change. Many leaders in the region ruled their states for decades (this being true for both monarchs and nominally republican leaders like Hosni Mubarak, Ali Abullah Saleh or Muammar Gaddafi) successfully withstanding many challenges to their authority. However, at the beginning of 2011 self-immolation of a Tunisian street vendor ignited an unprecedented shift in social attitudes and political activism across the Arab world. More than year and a half later political landscape of the region is profoundly altered. Tunisia and Egypt are in the middle of a political transformation leading (hopefully) to the establishment of democracy. Rulers of Morocco and Jordan have initiated reforms in order to satisfy the expectations of their populations. At the same time regimes in Algeria and Bahrain have been able to suppress social "disturbances" and maintain the status quo (for the time beign). At the other pole of this process we can see Libya and Syria, were popular dissatisfaction, met with hostility of the governments, lead to civil wars. Yemen experienced a mixed fate of both violent conflict and (tentative) political compromise. All those developments, known under the name of "Arab Spring" (with analogy to the Spring of Nations in 1848 and Autumn of Nations in 1989) have become a subject of rich political, media and academic commentary, as well as analyses.

The Arab Spring had become the subject of a research programme initiated at the Faculty of Political Science and Journalism, Adam Mickiewicz University in Poznań. In this framework researchers from several polish academic institutions (Adam Mickiewicz University, Koszalin University of Technology, Poznań University of Economics, Academia Ignatianum in Cracow, University of Warsaw, Pomeranian Academy in Słupsk, Łódź 
International Studies Academy, Institute for Western Affairs in Poznań and Higher School of Security in Poznań) conducted an in-depth analyses of events taking place in North Africa and Middle East in year 2011. The book entitled "The Arab Spring", edited by the project's coordinator Beata Przybylska-Maszner, provides the summary of their findings. The goals of the project, as stated in the introduction, were threefold: 1) "to describe and analyse the determinants of the processes which we could observe as part of the Arab Spring [...]"; 2) "to analyse and compare the events taking place in individual countries in the region and changes in the political, economic and social sphere"; 3) "to define and analyse the influence of selected external actors on the course of the Arab Spring, and to analyse the impact of the media".

The structure of the book reflects these main avenues of the research programme. First part deals with the "Determinants of the Arab Spring". Authors of these section's chapters describe and analyse the most important factors shaping the events in North Africa and Middle East. Social and economic problems of the Arab states received considerable attention, as major drivers of the discontent. Chapter authored by Marek Rewizorski provides a broad overview of the factors shaping the development (or lack of thereof) of the Arab economies and creating the social context in which the discontent had risen. Next chapter (by Ida Musiałkowska) is a detailed account of the current economic ties between the European Union and the states of the Mediterranean Basin, showing the extent of the economic interdependency between the regions. Mirosław Łakomy describes the role of "new media" (especially internet social networking tolls) in the events of the Arab Spring. This aspect of political activism has received considerable attention in the West and the author's findings support the view that they had indeed played a considerable role in the process of political change. Political transformations in the Arab world arouse anxiety in the West concerning the role of Islamic extremism and potential implications for terrorist activity. Two chapters of the reviewed book deal with those topics. Artur Wejkszner present jihadi views on democracy, while Aleksandra Zięba analyses the sources of terrorism in the Arab world. First part of the monograph is closed with chapter by Paweł Nieczuja-Ostrowski concerning the political ideas behind the protest movement and comparisons with East European experience of 1989.

Second part of the book describes the reactions of key external players to the changes in the region. Due to the regions considerable geopolitical significance, it is the object of interest for many important actors of international politics. Thus, the reactions of key outside powers are important factors shaping the dynamic of events in the Arab world. This part of the monograph starts with a chapter by Radosław Fiedler about the policies of Bush and Obama administrations towards democratization in the Middle East. In next chapter Wojciech Nowiak presents the Israeli perspective on the Arab Spring which is considerably more pessimistic than prevailing American and European views. In two subsequent chapters, Beata Przybylska-Maszner and Jarosław Jańczak analyse the EU response to the upheaval, from the perspective of community decision-making and Polish presidency respectively. Łukasz Donaj describes the position of the Russian Federation, which proved to be influential to the development of Libyan and Syrian crises. Swietłana Sydun presents Russian and Ukrainian views on the subject (curiously, in Russian). Two further chapters, authored by Aleksandra Kruk and Magdalena Musiał-Karg summarise the reactions of two European states - Germany and Switzerland respectively. Second part of the book closes with Bartosz Hordecki's chapter concerning the media portrayal of Muammar Gaddafii and especially his death. 
The final section of the monographs provides case studies of chosen states in which the Arab Spring has played out. It opens with a chapter by Marta Zobeniak which contains an overview of political situation in Algeria. It is followed by Witold Ostant's text about the circumstances of political transformation in Egypt. Subsequent chapter authored by Piotr Kwiatkiewicz provides interesting analysis of Arab Spring's demographic background with reference to situation in Egypt. Magdalena Lorenc summarizes the course of the Libyan civil war, while Przemysław Osiewicz analyses the complicated situation in Syria. The section concludes with two entries concerning the least known (at least in Poland) cases of upheaval in the Middle East. Jacek Raubo provides detailed overview of situation in Yemen (drawing a comparison with the sad fate of Somalia), while Marta Zobeniak provides overview of situation in Bahrain and its historic roots.

The book under review has several important strengths. First of all, it is an answer to current events, which arouse considerable political, academic and in fact popular interest. Second, it present a comprehensive approach to the subject. This is reflected in the very structure of the book, taking account of causes and dynamic of the process, its manifestations in different states, as well as reactions of key outside actors. Research benefits from the interdisciplinary nature of the research team. Core political science and international relations analyses is accompanied by the economics, media analyses and social psychology perspectives. It undeniably enriches the understanding of the processes in question. Thirdly, the book can be a useful compendium on the key aspects of the Arab Spring. The authors have taken account of the great majority of key aspects and cases of the analysed process. It can also be argued that this work suffers from two drawback. Although the book offers a comprehensive view of the Arab Spring it is not fully complete. The section concerning the causes and dynamics of the Arab Spring could arguably benefit from a deeper analyses of Arab states' political systems, which (diverse as they are) share some common features important for the understanding of political discontent. In the section concerning reactions of key outside players Turkey's omission is visible. This state has undoubtedly played an important role in the events of 2011 (for example as a "role model" for Muslim democracy or in the case of Syria). At the same time Switzerland has been included, while this state can hardly be classified as a "key" player in the region. Finally, some chapters are regarded as offering more of a recollection of key events than their in-depth background and analysis. However, in general "The Arab Spring" is a useful source of knowledge and reflection on one of the key issues in contemporary international relations. It can serve as a starting point for further studies of this subject.

Rafał WIŚNIEWSKI

Poznań

\section{J. Michalak, International Security Threats in the Biological Realm, Scientific Publishers Press Ltd, Lódź 2005, pp. 128.}

According to a traditional definition, security is freedom from threats posing a risk to the survival of the state. The broad definition of security threats in turn includes any action or sequence of events that threaten citizens' quality of life in a short period of time or restrict the scope for political choices made by the institutions of the state. Therefore, among others, 